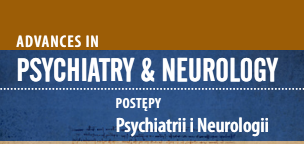

Adres do korespondencji:

Dorota Dużyk-Wypich

e-mail: capricorn.seven@onet.eu

\section{RECOVERY AND FAITH ${ }^{1}$ ZDROWIENIE I WIARA'}

\author{
Dorota Dużyk-Wypich
}

The Association "Open the Doors" in Cracow, Poland

Stowarzyszenie "Otwórzcie Drzwi”, Kraków, Polska

Submitted/Otrzymano: 29.05.2018

Accepted/Przyjęto do druku: 10.06.2018

(...) German word Erfahrung - experience, derives from the verb fahren - to travel. Travelling takes time, not seldom a whole life, it leads through trials, mistakes, lapses, break-downs, but also moments of joy, peace, and happiness, however relative this concept may be. This journey takes endurance and patience. And how can one be patient, when he or she encounters mental suffering? How to endure the travel and not to disembark underway?

In mental illness, we disembark the train of life, although we are still alive. But this life becomes so difficult, that we wander into psychosis, delusions, depression, suicidal thoughts and attempts. Does faith help us get out of this? Does it help to recover? I am not able to answer this question unequivocally.

There are many shades to faith, it depends on what our mental condition is, how we perceive ourselves, the others, the world. There is no sheer spirituality, as in addition to it there is also our psyche and emotions, encompassed by boundaries of the body. Spirituality is connected with sensing, imaginations, feelings, experiences. And sometimes it is contaminated with ill-perception of the self and of the others, including God.

In order to recover you have to want it really hard. Even if you really want it, recovery can be an extremely

\footnotetext{
${ }^{1}$ Fragments of the lecture delivered at the $16^{\text {th }}$ Community Psychiatry Forum "Empowerment and Recovery. To give hope" in Cracow, 24-25 May 2018. The full text will be printed in the "Dla Nas" magazine, published by the Association "Open the Doors" (Cracow). The author is the editor-in-chief of this magazine, the Cogito Expert and a member of the Cogito Academy of Leaders that gathers persons with the experience of mental crisis, who are prepared to public activity aimed at restoring and ensuring respect for rights and dignity of people with such experience. Reflection on the role of faith may vastly broaden professional imagination of people assisting in recovery. Lack of it, along with a substantial number of prevalent stereotypes that are present in therapeutic schemas justifies presentation of this text to the "AoPN" readers (ed.).
}

[...] Niemieckie słowo Erfahrung - doświadczenie, pochodzi od czasownika fahren - podróżować. Podróż wymaga czasu, trwa całe życie, prowadzi przez próby, błędy, potknięcia, załamania, ale też chwile radości, pokoju, szczęścia, jakkolwiek względne jest to pojęcie. Ta droga potrzebuje wytrwałości i cierpliwości. A jak być cierpliwym, skoro spotyka nas cierpienie psychiczne? Jak wytrwać w podróży i nie wysiąść w biegu?

$\mathrm{W}$ chorobie psychicznej wysiadamy z pociągu życia, chociaż wciąż żyjemy. Ale to życie staje się tak trudne, że wędrujemy w psychozę, urojenia, depresję, myśli i próby samobójcze. Czy wiara pomaga nam z tego wyjść? Czy pomaga zdrowieć? Nie mogę jednoznacznie odpowiedzieć na to pytanie.

Wiara ma wiele odcieni, zależy w jakiej jesteśmy kondycji psychicznej, jak odbieramy siebie, ludzi, świat. Nie ma czystej duchowości, gdyż oprócz niej jest w nas psychika, emocje, do tego zamknięte w ciele. Duchowość jest związana z przeżywaniem, z wyobrażeniami, odczuciami, doświadczeniami. A czasem jest skażona chorobowym postrzeganiem siebie i świata, w tym również Boga.

Żeby wyzdrowieć, trzeba tego naprawdę chcieć. Nawet jeśli bardzo się chce, niekiedy jest to wyjątkowo

${ }^{1}$ Fragmenty wystapienia przedstawionego na XVI Forum Psychiatrii Środowiskowej „Umacnianie i zdrowienie. Dać nadzieję” w Krakowie, 24-25 maja 2018. Pełen tekst zostanie opublikowany w czasopiśmie „Dla Nas” wydawanym przez Stowarzyszenie „Otwórzcie Drzwi” (Kraków). Autorka jest redaktorem tego czasopisma, ekspertem Cogito, członkinią Akademii Liderów, skupiającej osoby z doświadczeniem kryzysu psychicznego, przygotowane do publicznej działalności na rzecz poszanowania praw i godności osób z takim doświadczeniem. Refleksja nad rolą wiary może niezwykle poszerzać profesjonalną wyobraźnię osób pomagających w zdrowieniu. Jej brak wraz z pokaźną liczbą przemożnych stereotypów funkcjonujących na ten temat $\mathrm{w}$ schematach terapeutycznych uzasadnia przedstawienie tego tekstu czytelnikom „PPiN” (red.). 
difficult task. It would also be good to know what you want to recover from; sometimes it takes years to acquire such knowledge - years of therapy, crises, remissions and recurring downfalls.

(...) For years I had not felt good in my body. On my way of therapy, I met people who did not feel good in theirs, either. Faith and religion have such a powerful message that most of us have delusions of religious nature. These are, now and then, beautiful experiences of ecstasy, illuminating flashes of inspiration - I understand everything! - deep affection in church, where suddenly you can feel an overwhelming presence of God. Then these feelings are taken away by medicine, treatment, post-psychotic depression. You are left with a question: was this, what I had experienced, a mere delusion?

But apart from miraculous sensations, also nightmares appear: rejection by God, punishment, damnation, infernal ordeal already on earth, cruel fight with Satan, piercing feeling of guilt.

Just as one's psyche can ail, so can his or her spirituality. Sadly, so few therapists take up talks about spirituality and faith. And how good it would be to make an attempt at healing both these human dimensions at the same time... Luckily, some therapist propose to their patients talks with priests who are experienced in psychotherapy, too. Nevertheless, these priests, who do not know much about mental illness, should be educated so that they know how to handle penitents experiencing a crisis. But there are also other roads on which we may end up.

Everybody has his or her own "introduction to meeting with God", as father Catalan recalls [1]. This introduction may be painful, as faith is not a simple matter, it is often a road through purgatory, and may take many, many years. This was my case - in my journey through psychiatry, I have met people who, after nightmarish experiences in psychosis and depression turned away from God, or were not able to withstand a mass in church - their emotions had been so strong. Also other behaviours appeared, like overly religious attitude, incessant prayer - when I stop praying, I will stop being a good Christian. And of course I have to admonish others, recall them about God in order to save them, and also show God how much I love Him. Both the former and the latter attitude are disturbing and cannot pose an example of spirituality. Very seldom did I see a balanced, mature faith, full of peace, not patronising, but still transparent and firm. It is hard to find it among the mentally ill. But it comes to life when we go out of a crisis and gain some perspective on things.

Faith helps to heal, as long as it becomes healed itself. Healed and freed from our complexes, injuries, fears, ailing self-love and hardships in relationships with others. Of course, nobody is perfect, and to an extent some fears and concerns will accompany us in our journey. Still, one can heal them to such an extent, that they no longer disturb our lives and no longer are an escape into illness - trudna sztuka. Jeszcze dobrze byłoby wiedzieć, z czego się chce wyzdrowieć, a taką wiedzę nabywamy czasami przez lata, lata terapii, kryzysów, remisji i ponownych wpadek.

[...] Przez lata nie było mi dobrze w swoim ciele. I na drodze leczenia spotkałam ludzi, którym też nie było w nim dobrze. Wiara i religia mają tak silny przekaz, że większość z nas miała urojenia o treści religijnej. Zdarzało się, że były to piękne przeżycia ekstazy, objawiającego olśnienia - wszystko rozumiem! - wzruszeń w kościele, gdzie nagle czuło się wszechogarniającą obecność Boga. A potem te odczucia odbierały leki, leczenie, depresja popsychotyczna. Pozostawało pytanie: czy to, co wtedy przeżywałam, to było tylko urojenie?

Ale oprócz cudownych doznań pojawiały się też koszmary: odrzucenie przez Boga, kara, potępienie, męki piekielne już tu na ziemi, okrutna walka $\mathrm{z}$ szatanem, przeszywające poczucie winy.

Tak jak choruje psychika, choruje i duchowość. Jakże niewielu terapeutów podejmuje się rozmów o duchowości i wierze. A jak dobrze byłoby podjąć próbę uzdrowienia tych dwóch ludzkich sfer naraz... Na szczęście niektórzy proponują pacjentom rozmowy z księżmi mającymi doświadczenie w psychoterapii. A tych księży, którzy niewiele wiedzą o chorobie psychicznej, należałoby przeszkolić, żeby wiedzieli, jak postępować z penitentami w kryzysie. Ale są też inne drogi, na które możemy trafić.

Każdy ma swój „wstęp do spotkania z Bogiem”, jak wspomina ojciec Catalan [1]. Bywa on bolesny, bo wiara nie jest prosta, jest często drogą przez mękę, która czasami trwa długie lata. Tak było ze mną, a w swojej podróży przez psychiatrię spotykałam ludzi, którzy po koszmarnych przeżyciach w psychozie i $\mathrm{w}$ depresji odwracali się od Boga albo nie byli w stanie wytrzymać na mszy w kościele, tak wielkie były ich emocje. Pojawiały się i inne zachowania, jak przesadna religijność, nieustanna modlitwa - bo jak przestanę się modlić, nie będę dobrym chrześcijaninem. No i muszę pouczać innych, przypominać im o Bogu, żeby ich zbawić, a także pokazać Bogu, jak bardzo Go kocham. I jedna, i druga postawa niepokoiły i nie mogły być wzorem duchowości. Bardzo rzadko widziałam zrównoważoną wiarę, dojrzałą i pełną pokoju, nie narzucającą się, a jednak przejrzystą i pewną. Trudno ją spotkać wśród ludzi cierpiących psychicznie. Ale pojawia się ona, kiedy wychodzimy z kryzysu i nabieramy dystansu.

Wiara pomaga zdrowieć, jeśli sama zostanie uzdrowiona, uwolniona od naszych kompleksów, zranień, lęków, chorującej miłości własnej i trudności w relacjach z ludźmi. Oczywiście nikt nie jest doskonały i jakaś część obaw i lęków będzie nadal towarzyszyła nam w podróży. Można jednak uzdrowić je tak, żeby nie zakłócały nam życia i nie były ucieczką w chorobę, a to pociąga za 
this entails acceptance of certain limitations and failures without psychical break-down. I did not talk about God with therapists, like most of the mentally ill do not - maybe there was fear in us: he may think I have religious delusions, or that God is my projection of an unsatisfied need for love and security. That is a shame - maybe our faith would be healed sooner...

So God led me another way, as I have no doubt that it is His deed.

For years I have been thinking that perhaps this God exists, but I have not invited Him to my life, nor have I gone to church. Masses bored me and made me tired. On the other hand, in psychosis I communed with angels, saints, the dead, I fought with Satan. In depression, the thought that I would end up in hell did not prevent me from suicidal attempts. The only solution I saw in order to stop suffering was to stop living. I am still of the opinion, that suicide is not a sin, if one does not withstand the suffering. One has to be really strong to go on with his or her life. In depression faith does not help, you are not able to pray, God's love is dwarfed by the feeling of guilt.

However, it was in my depression - after devastating experiences of long manic and psychotic periods, that a thought entered my mind - I have never been confirmed and I would like to adopt a mature faith. It must have been You, Heavenly Father, who knocked at my door.

(...) And thus my faith started to recover. With a course of time, the psyche followed.

Depression subsided, but it was hard to me to liberate from magical thinking. I do not mean only magical agency, but also the magic of life, longing for miracularity. So God left me this magic, such a little enchantingness of everyday life. Now it sometimes leaves me for long, so I enliven this enchantingness with music, admiration of nature, and recently with a fabulous patterns on my furniture that I painted myself. In this way I familiarised solitude after my husband's demise.

When my father passed away, we went with my mum to bid him farewell to a hospital morgue. There came a caravan that was to take away my father's body for cremation, and at the very moment when undertakers carried in a simple wooden coffin, a hackney carriage drove by. My dad loved "The Enchanted Carriage" by Gałczyński, he enjoyed citing it and I assumed that it had been on this vehicle that my dad had gone to heaven. And that is how carriages became my magic conversation with God. They are quite aplenty in the centre of Cracow, but they came my way in many an unexpected place. Even while I went to Midnight Mass after many, many years, feeling so very sad that I was going alone, suddenly a carriage passed by in front of the church. I believe it had been God who sent it. I still wave to carriages in my soul, greeting God and my dad.

Introduction to faith was very painful; many people start this way, not only persons after mental crises. The saint also have difficult introductions... sobą przyjęcie ograniczeń i porażek bez psychicznego załamania. Nie rozmawiałam z terapeutami o Bogu, jak większość chorujących psychicznie - może był w nas lęk: a nuż pomyśli, że mam urojenia o treści religijnej, albo że Bóg jest moją projekcją niezaspokojonej potrzeby miłości i bezpieczeństwa. A szkoda, może wiara zostałaby uzdrowiona szybciej...

Bóg więc poprowadził mnie inaczej, bo nie wątpię, że to Jego dzieło.

Przez lata myślałam, że ten Bóg chyba istnieje, ale nie zapraszałam Go do mojego życia, nie chodziłam do kościoła, msze nudziły mnie i męczyły. A w psychozie obcowałam z aniołami, świętymi, zmarłymi, walczyłam z szatanem. W depresji przed popełnieniem samobójstwa nie powstrzymywała mnie myśl, że wyląduję w piekle. Jedynym wyjściem, jakie widziałam, żeby przestać cierpieć, było przestać żyć. Do tej pory nie uważam, że samobójstwo to grzech, jeżeli człowiek nie wytrzymuje cierpienia. Trzeba mieć dużo siły, żeby żyć dalej. W depresji wiara nie pomaga, człowiek nie jest w stanie się modlić, poczucie winy przysłania miłość Bożą.

A jednak właśnie $\mathrm{w}$ depresji po wyniszczających przejściach długiej manii i psychozy zaświtała myśl, że przecież nie byłam bierzmowana i chciałabym przyjąć dojrzałą wiarę. To pewnie Ty, Ojcze Niebieski, pukałeś do mnie.

[...] I tak moja wiara zaczęła zdrowieć. Powoli zdrowiała i psychika.

Depresja przeszła, ale trudno mi było wyzwolić się od myślenia magicznego. Nie chodzi tutaj tylko o sprawczość magiczną, ale też o magię życia, pragnienie cudowności. No i Bóg zostawił mi tę magię, taką małą czarowność dnia codziennego. Teraz zdarza się, że długo jej nie czuję, ożywiam ją więc muzyką, zachwytami przyrodą, a ostatnio bajkowym pomalowaniem przez siebie mebli $\mathrm{w}$ mieszkaniu. Tym sposobem oswoiłam samotność po śmierci męża.

Kiedy zmarł mój tata, poszłyśmy z mamą pożegnać się z nim w szpitalnym prosektorium. Przyjechał karawan, który miał odwieźć jego ciało do kremacji, i w chwili, kiedy wnosili prostą drewnianą trumnę, koło szpitala przejechała dorożka. Tato uwielbiał „Zaczarowaną dorożkę" Gałczyńskiego, lubił ją recytować i uznałam, że właśnie nią odjechał do nieba. I tak dorożki stały się moją magiczną rozmową z Bogiem. W centrum Krakowa jest ich dużo, ale pojawiały się na mojej drodze w różnych nieoczekiwanych miejscach. Nawet wtedy, kiedy poszłam na pasterkę po latach i było mi tak smutno, że idę sama, przed zimowym nocnym kościołem przejechała dorożka. Wierzę, że to Bóg ją przysłał. Nadal w duszy macham dorożkom, pozdrawiam Boga i tatę.

Wstęp do wiary był bardzo bolesny, doświadcza tego wielu ludzi, nie tylko po kryzysach psychicznych. Święci też mają trudne wstępy... 
Healing our faith, we heal ourselves. Recovery means normal relations with people, no longer burdened with overwhelming complexes, without fear of the others; it is openness, but also assertiveness. It is an awareness that God loves me and helps me in life, and it also mean awareness that I have to take care of myself, for that alone that my loved ones are already on the other side. It is acceptance of death as a part of life, it is faith that the loved ones live in another world.

Therapists, do help us heal our faith. Have no fear of talks about God, do get to know our spirituality. Do accompany us in the journey towards a wise and positive faith (...).
Uzdrawiając wiarę, uzdrawiamy siebie. A zdrowienie to normalne relacje z ludźmi, już bez obezwładniających kompleksów, bez lęku przed innymi, to otwartość, ale też asertywność. To świadomość, że Bóg mnie kocha i pomaga w życiu, a także świadomość, że sama mam się sobą opiekować, choćby dlatego, że moi najbliżsi są już po drugiej stronie. To przyjęcie śmierci jako części życia, wiara, że ci kochani żyją w innej postaci.

Terapeuci, pomóżcie nam uzdrawiać naszą wiarę. Nie bójcie się rozmów o Bogu, poznajcie naszą duchowość. Towarzyszcie nam w podróży do mądrej, dobrej wiary $[\ldots]$.

Translation: Jan Godyń

References/Piśmiennicłwo

1. Catalan JF. Duchowość a psychologia. Kraków: Wydawnictwo eSPe; 2007. 